\title{
ANALISIS KETERSEDIAAN DAN ASUPAN ZAT GIZI PADA MENU BUKA PUASA PONDOK PESANTREN NURUL HAKIM
}

\author{
Nurul Kamila Paradisa ${ }^{1}$, Reni Sofiyatin ${ }^{2}$, Ni Ketut Sri Sulendri ${ }^{3}$ dan AASP Chandradewi ${ }^{4}$ \\ JurusanGizi, PoltekkesKemenkesMataram, Indonesia \\ Jl. Praburangkasari Dasan Cermen, Sandubaya Kota Mataram \\ Telp./Fax. (0370) 633837 \\ Email : jurnalgiziprima1@gmail.com \\ Nurul Kamila Paradisa, Poltekkes Kemenkes Mataram, Indonesia \\ Email : nkp.diisa@gmail.com
}

\begin{tabular}{l} 
Article Info \\
Article history: \\
Received Jan $12^{\text {th }}, 201 \mathrm{x}$ \\
Revised Feb $20^{\text {th }}, 201 \mathrm{x}$ \\
Accepted Mar $26^{\text {th }}, 201 \mathrm{x}$ \\
\hline
\end{tabular}

Keyword:

iftar menu, availability, nutrient intake

\begin{abstract}
PT)
The 2013 Risekesdas data for short and thin 13th-15th adolescents in Indonesia is $35.5 \%$ and $11.1 \%$ and NTB is one of the provinces with more than national travel. Nutritional problems attack all adolescents including the boarding school teenagers. Fulfillment of nutrients is very dependent on the organization of cottage meals. So that the availability of nutrients in the cottage must meet the adequacy of the nutrition of students who can be seen from the menu provided, enough nutrients and varied every day is not lost in the Fasting month. The variety of materials used depends on the funds provided. The observation result is that the budget for the Nurul Hakim boarding school meal is IDR 250,000 / month with a less varied menu. Researchers are interested in analyzing the availability with the contribution of nutrients in the organization of the meal iftar.
\end{abstract}

Copyright () JurnalGizi Prima All rights reserved.

\section{PENDAHULUAN}

Remaja adalah masa transisi antara masa anak-anak menuju dewasa (Arisma MB, 2009), yang membutuhkan zat gizi optimal agar tidak terjadi masalah gizi pada remaja mana saja tidak terkecuali remaja pondok pesantren (Pakar Gizi Indonesia, 2016). Pondok pesantren adalah lembaga pendidikan Islam yang memiliki asrama di dalamnya sebagai tempat tinggal murid yang harus diperhatikan pertumbuhan dan perkembangannya.

Dari data hasil Riskesdas (2013) menunjukkan bahwa pravelensi remaja pendek dan kurus di Indonesia berturut-turut adalah $35,15 \%$ dan $11,1 \%$, provinsi NTB adalah salah satu provinsi dengan pravelensi remaja pendek dan kurus melebihi pravelensi nasional. Salah satu cara pencegahan masalah gizi pemenuhan zat gizi di pondok pesantren.

Remaja yang tinggal di pondok pesantren sangat bergantung pada makanan yang disediakan pondok (Abdulkarem et al, 2013 dalam Tiurma et al, 2016). Sehingga ketersediaan makanan harus memenuhi kecukupan gizi.

Pada saat berpuasa, tubuh akan mengalami pengurangan 10\%-40\% kebutuhan zat gizi sehari-hari. Pemenuhan zat gizi untuk buka puasa sama dengan pemenuhan untuk makan malam, yang harusnya memenuhi 30\% angka kecukupan zat gizi (Kemenkes RI, 2014).

Dari hasil penelitian Rukmini L dan Suranadi L 2015. didapatkan hasil bahwa ketersediaan zat gizi energi dan protein kurang dari AKG yakni sebesar $63,1 \%$ dan $54 \%$. Selain itu pada penelitian lainnya yakni 
penelitian Anisa, et al 2017 dalam penelitian hubungan ketersediaan pangan dan asupan zat gizi dengan kadar hemoglobin santriwati saat puasa ramadhan, menunjukkan bahwa ketersediaan pangan di pondok pesantren tergolong kurang yaitu 81,2\% sedangkan standar skor Pola Pangan Harapan berdasarkan Standar Pelayanan Minimal.

Dari uraian diatas, peneliti tertarik untuk menganalisis ketersediaan dan asupan zat gizi makro dan mikro pada penyelenggaraan makan menu buka puasa pondok pesantren Nurul Hakim.

\section{METODE PENELITIAN}

Penelitian ini adalah penelitian yang bersifat observasional deskriptif dengan pendekatan Crossectional, dengan sampel 63 orang didapatkan dari hasil perhitungan rumus Slovin dengan ketelitian 10\%.

Data ketersediaan didapatkan dengan menulis menu dan menimbang bahan makanan yang akan diolah, data asupan didapatkan dengan menimbang makanan yang didapatkan dari pondok dan menulis makanan yang dikonsumsi dari luar.

Analisis data dilakukan dengan mencari berat mentah matang, menentukan berat yang dapat dimakan, menghitung zat gizi dan minyak yang diserap kemudian dibandingkan dengan $30 \%$ AKG remaja putri usia 13th-15th.

\section{HASIL PENELITIAN}

Karakteristik Sampel

Sampel pada penelitian sebanyak 63 orang. Pemenuhan zat gizi di pondok didapatkan dari makanan berbuka dan makanan sahur. Kecukupan zat gizi untuk buka puasa harus memenuhi 30\%AKG yakni energi 637,4 kkal, protein 20,7 gram, lemak 21,3 gram, karbohidrat 87,6 gram dan fe 7,8mg

\section{Menu Buka Puasa}

Tabel 1. Menu buka puasa pondok pesantren Nurul Hakim

\begin{tabular}{lll}
\hline \multicolumn{3}{c}{ Menu hari ke- } \\
\hline \multicolumn{1}{c}{1} & \multicolumn{1}{c}{2} & \multicolumn{1}{c}{3} \\
\hline Nasi & Nasi & Nasi \\
Abon ikan tongkol & Ayam Bumbu Merah & Telur Dadar \\
Pecel & Bihun Goreng & Pecel \\
\hline
\end{tabular}

\section{Ketersediaan Zat Gizi}

Ketersediaan Energi

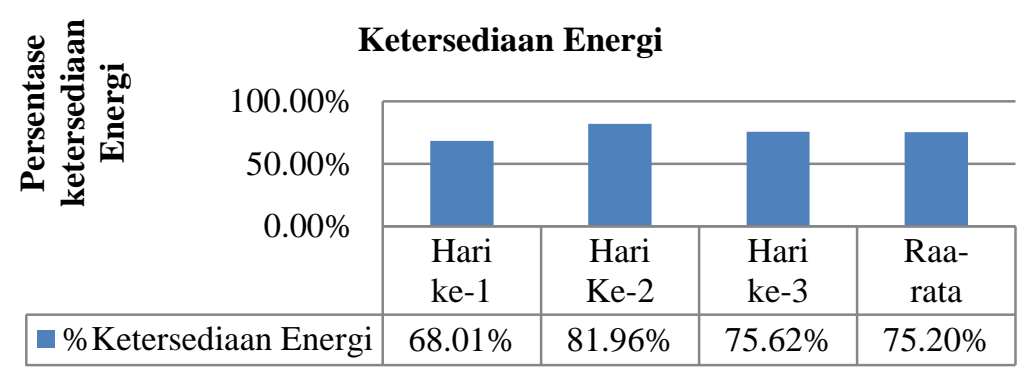

Gambar 1. Ketersediaan Energi

\section{Ketersediaan Protein}

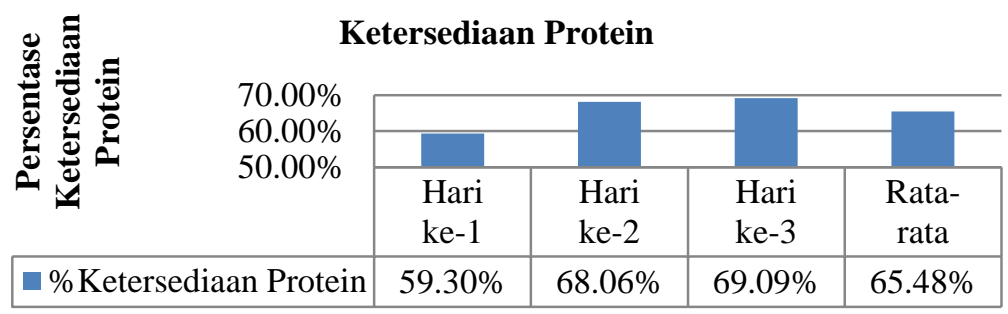


Gambar 2. Ketersediaan Protein

Ketersediaan Lemak

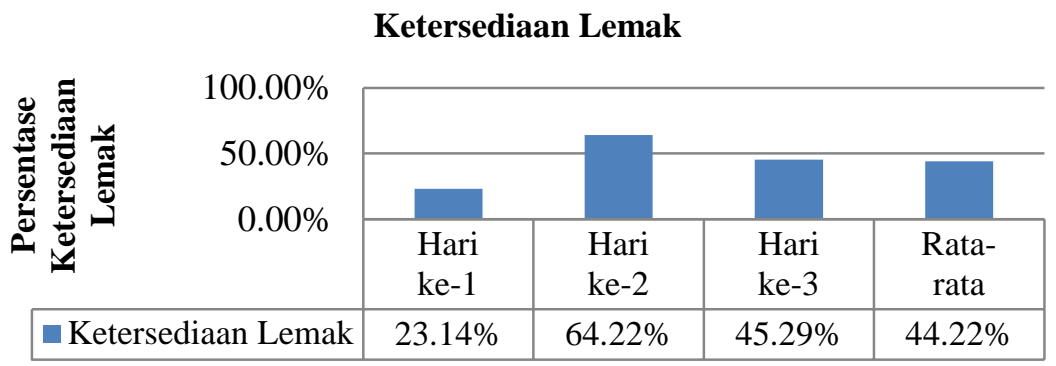

Gambar 3. Ketersediaan Lemak

Ketersediaan Karbohidrat

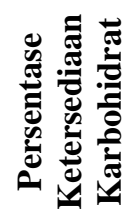

Ketersediaan Karbohidrat

\begin{tabular}{|c|c|c|c|c|}
\hline & $\begin{array}{l}\text { Hari } \\
\text { ke-1 }\end{array}$ & $\begin{array}{l}\text { Hari } \\
\text { ke-2 }\end{array}$ & $\begin{array}{l}\text { Hari } \\
\text { ke-3 }\end{array}$ & $\begin{array}{c}\text { Rata- } \\
\text { rata }\end{array}$ \\
\hline Ketersediaan Karbohidrat & $97.8 \%$ & $98.4 \%$ & $96.8 \%$ & $97.7 \%$ \\
\hline
\end{tabular}

Gambar 4. Ketersediaan Karbohidrat

Ketersediaan Zat Besi (Fe)

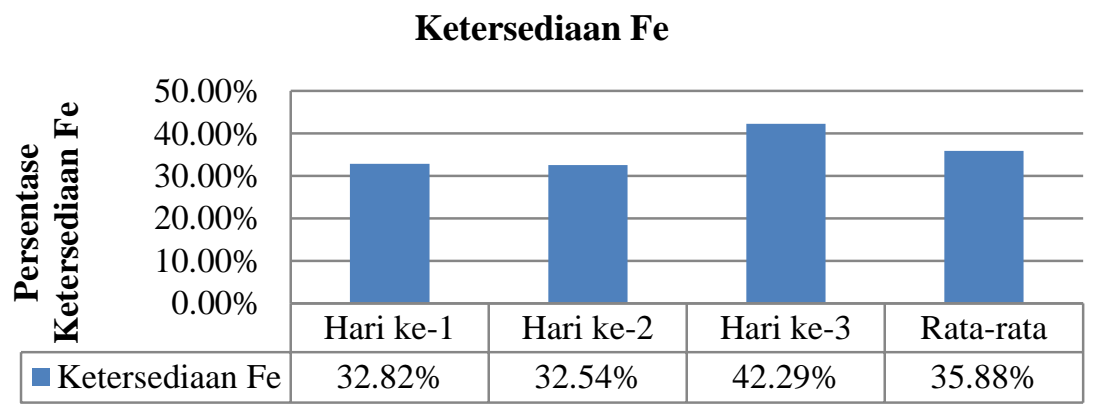

Asupan Zat Gizi Buka Puasa

Asupan dari pondok

Tabel 2 Asupan zat gizi buka puasa dari dalam pondok

\begin{tabular}{lccccc}
\hline \multirow{2}{*}{ Zat Gizi } & Energi (Kkal) & Protein $(\mathrm{g})$ & Lemak (g) & Karbohidrat $(\mathrm{g})$ & Fe (mg) \\
\hline Asupan & 484,77 & 13,6 & 17,29 & 80,95 & 2,92 \\
\hline 30\%AKG & 637,5 & 20,7 & 21,3 & 87,6 & 7,8 \\
\hline \%Asupan & 76,05 & 66,14 & 81,18 & 92,41 & 37,46 \\
\hline
\end{tabular}

Sumber : Data Primer 2019 
Tabel 3 Asupan zat gizi buka puasa dari luar pondok

\begin{tabular}{lccccc}
\hline Zat Gizi & Energi (Kkal) & Protein $(\mathrm{g})$ & Lemak $(\mathrm{g})$ & Karbohidrat $(\mathrm{g})$ & $\begin{array}{c}\mathrm{Fe} \\
(\mathrm{mg})\end{array}$ \\
\hline Asupan & 38,70 & 1,21 & 2,00 & 4,37 & 0,26 \\
\hline 30\%AKG & 637,5 & 20,7 & 21,3 & 87,6 & 7,8 \\
\hline \%Asupan & 6,07 & 5,85 & 9,37 & 4,99 & 3,38 \\
\hline
\end{tabular}

Sumber : Data Primer 2019

Asupan dari dalam dan luar pondok

Tabel 4 Asupan zat gizi buka puasa dalam dan luar pondok

\begin{tabular}{lccccc}
\hline \multicolumn{1}{c}{ Zat Gizi } & Energi (Kkal) & Protein $(\mathrm{g})$ & Lemak $(\mathrm{g})$ & Karbohidrat $(\mathrm{g})$ & Fe $(\mathrm{mg})$ \\
\hline Asupan & 523,4 & 14,9 & 19,29 & 85,32 & 3,18 \\
\hline 30\%AKG & 637,5 & 20,7 & 21,3 & 87,6 & 7,8 \\
\hline \%Asupan & 82,13 & 71,99 & 90,55 & 97,4 & 40,8 \\
\hline Kategori & Sedang & Kurang & Sedang & Sedang & Defisit \\
\hline Sumber
\end{tabular}

Sumber : Data Primer 2019

Distribusi Tingkat Konsumsi Sampel

Tabel 8 Distribusi tingkat konsumsi sampel

\begin{tabular}{|c|c|c|c|c|c|c|c|c|c|c|}
\hline \multirow{3}{*}{ Kategori } & \multicolumn{10}{|c|}{ Zat Gizi } \\
\hline & \multicolumn{2}{|c|}{ Energi } & \multicolumn{2}{|c|}{ Protein } & \multicolumn{2}{|c|}{ Lemak } & \multicolumn{2}{|c|}{ Karbohidrat } & \multicolumn{2}{|c|}{$\mathrm{Fe}$} \\
\hline & $\mathrm{n}$ & $\%$ & $\mathrm{n}$ & $\%$ & $\mathrm{n}$ & $\%$ & $\mathrm{n}$ & $\%$ & $\mathrm{n}$ & $\%$ \\
\hline Baik & 3 & 4,76 & 1 & 1,59 & 22 & 34,92 & 28 & 44,44 & 0 & 0 \\
\hline Sedang & 34 & 43,97 & 5 & 7,94 & 12 & 19,05 & 35 & 55,56 & 0 & 0 \\
\hline Kurang & 24 & 38,10 & 28 & 44,44 & 17 & 26,98 & 0 & 0 & 0 & 0 \\
\hline Defisit & 2 & 3,17 & 29 & 46,03 & 12 & 19,05 & 0 & 0 & 63 & 100 \\
\hline Total & 63 & 100 & 63 & 100 & 63 & 100 & 63 & 100 & 63 & 100 \\
\hline
\end{tabular}

\section{PEMBAHASAN}

\section{Karakteristik Sampel}

Sampel pada penelitian merupakan remaja putri usia 13th-15th, yang tinggal di asrama pondok pesantren Nurul Hakim. Pada masa ini, remaja mengalami percepatan pertumbuhan sehingga membutuhkan zat gizi yang tinggi baik makro dan mikro (Pakar Gizi Indonesia, 2016). Salah satu zat gizi yang perlu diperhatikan seperti zat besi $(\mathrm{Fe})$ yang diperlukan pada masa remaja yang merupakan salah satu komponen sel darah merah (Hemoglobin). Hasil penelitian Nur Hidayah, et al (2016) didapatkan bahwa pada usia 14th-18th rentang usia remaja putri mengalami menstruasi. Menstruasi (kehilangan darah secara alami) dialami wanita usia subur setiap bulan.

\section{Menu buka puasa}

Menu yang di hidangkan di pondok pesantren Nurul Hakim dihari pertama dan ketiga terdiri atas makanan pokok, lauk hewani, dan sayur. Sedangkan dihari kedua menu terdiri dari dua sumber makanan pokok dan lauk hewani. Dalam pesan umum gizi seimbang dikatakan bahwa kita harus membiasakan mengkonsumsi makanan tinggi protein, mengkonsumsi banyak sayur dan buah (Kemenkes RI, 2014). Dalam protein hewani dan nabati terdapat asam amino yang berpengaruh terhadap pertumbuhan manusia (Almatsier, 2009). Sehingga dalam satu hidangan sebaiknya terdiri dari dua sumber protein yakni protein hewani dan protein nabati. 


\section{Ketersediaan Energi}

Ketersediaan energi untuk buka puasa yang yang disediakan pondok pesantren Nurul Hakim terendah pada hari pertama dan tertinggi pada hari kedua diebabkan karena Dihari kedua bahan makanan sumber energi yang disediakan berasal dari beras, dan bihun. Rata-rata ketersediaan energi untuk ketiga harinya dalam kategori kurang yakni sebesar 76,18\%. Penelitian ini sejalan dengan penelitian Rukmini L dan Suranadi L (2015) ketersediaan energi yang disediakan kurang $(64,1 \%)$ dari AKG. Rata-rata ketersediaan energi untuk ketiga harinya dalam kategori kurang yakni sebesar $76,18 \%$ dari $30 \%$ AKG yang dianjurkan untuk buka puasa. Penelitian ini sejalan dengan penelitian Rukmini L dan Suranadi L (2015) di pondok pesantren Nurul Hakim, ketersediaan energi yang disediakan kurang $(64,1 \%)$ dari AKG.

\section{Ketersediaan Protein}

Ketersediaan protein terendah dihari pertama dan tertinggi dihari ketiga. Hal ini disebabkan karena makanan sumber protein yang disediakan lebih banyak dari biasanya, karena keesokan harinya sudah libur lebaran.Rata-rata ketersediaan protein yang kurang ini disebabkan oleh jumlah bahan makanan yang disediakan pondok pesantren Nurul Hakim masih kurang, karena pada saat belanja, petugas hanya memperkirakan bahan makanan yang dibeli cukup untuk semua konsumen yang dilayani. Penelitian ini sejalan dengan penelitian Rukmini L dan Suranadi L (2015) bahwa protein yang disediakan kurang (54,0\%). Penelitian ini juga sejalan dengan penelitian Sudrahat dan tiurma (2016) bahwa tingkat ketersediaan protein di pondok pesantren Darul Arqam Garut belum memenuhi AKG sampel.

\section{Ketersediaan Lemak}

Lemak terendah disediakan pada hari pertama dan terbanyak pada hari kedua. Bahan makanan sumber lemak yang disediakan pondok pesantren dihari pertama berupa ikan tongkol yang merupakan bahan makanan rendah lemak. Dihari kedua sumber lemak yang disediakan berupa ayam yang merupakan termasuk kedalam golongan bahan makanan sumber tinggi lemak karena daging masih dengan kulitnya.Rata-rata ketersediaan lemak kurang berbanding terbalik dengaan penelitian Sudrajat dan tiurma (2016) bahwa tingkat ketersediaan lemak di pondok pesantren Darul Arqam Garut dihari ke satu dan ke dua melebihi 100 persen AKG.

\section{Ketersediaan Karbohidrat}

Karbohidrat terendah disediakan pada hari ketiga dan terbanyak pada hari kedua dihari kedua bahan makanan sumber karbohidrat yang disediakan ada dua macam yakni berasal dari beras, dan bihun. Rata-rata ketersediaan karbohidrat yang kurang ini sejalan dengan penelitian Sudrajat dan tiurma (2016) bahwa tingkat ketersediaan karbohidrat di pondok pesantren Darul Arqam Garut belum memenuhi AKG.

\section{Ketersediaan Zat Besi (Fe)}

Fe terendah disediakan pada hari kedua dan terbanyak pada hari ketiga.Ketersediaan fe terbanyak pada hari ketiga disebabkan karena bahan makanan yang disediakan pada hari ketiga menyumbang lebih besar fe dalam 100g bahan makanan, daripada bahan makanan sumber fe dihari lainnya. Rata-rata ketersediaan fe yang kurang ini sejalan dengan penelitian Sudrajat dan tiurma (2016) bahwa tingkat ketersediaan fe di pondok pesantren Darul Arqam Garut belum memenuhi AKG.

\section{ASUPAN ZAT GIZI}

\section{Asupan dari dalam pondok}

Asupan zat gizi dari pondok berasal dari makanan yang disediakan pondok pesantren untuk buka puasa. Rata-rata ketersediaan zat gizi untuk buka puasa dalam kategori kurang asupan dalam pondok menyumbang zat gizi energi, lemak dan karbohidrat $>75 \%$, protein $<70 \%$ dan fe $<40 \%$. Hal ini menandakan bahwa, makanan yang didistribusikan kepada santriwati tidak merata. Seharusnya dengan ketersediaan zat gizi yang kurang tentu, asupan santriwati akan kurang pula disebabkan karena pada saat mengambil makanan, untuk nasi santriwati mengambil sendiri dan untuk lauk diambilkan oleh petugas masak. Alat berupa sendok sayur dan tanpa alat atau menggunakan tangan petugas yang digunakan untuk pemorsian belum mampu mendistribusikan lauk secara merata.

\section{Asupan dari luar pondok}

Asupan zat gizi dari luar pondok berasal dari makanan yang didapatkan dari luar baik yang dibeli berupa gorengan, pop mie maupun makanan yang dibawakan orang tua santriwati seperti abon dan kurma Makanan yang dikonsumsi dari luar pondok pesantren menyumbang <10\% dari 30\%AKG Meskipun mendapat makanan dari luar pondok, zat gizi yang disumbangkan tidak terlalu banyak, sehingga belum dapat membuat asupan santriwati menjadi baik. 


\section{Asupan dari luar dan dalam pondok}

Makanan yang didapatkan dari luar dan dalam pondok belum mampu memenuhi kecukupan 30\% AKG santriwati untuk buka puasa. Karena jumlah yang disediakan pondok kurang dan makanan yang didapatkan dari luar tidak banyak jumlahnya dan hanya menyumbang sedikit zat gizi. Sehingga asupan zat gizi santriwati belum dapat dikatakan baik.

\section{DISTRIBUSI TINGKAT ASUPAN BUKA PUASA SAMPEL Asupan Energi}

Tingkat asupan energi dari 63 orang 3 orang (4,76\%) memiliki tingkat asupan baik, 34 orang $(53,97 \%)$ sedang, 24 orang $(38,10 \%)$ kurang dan 2 orang $(3,17 \%)$ defisit. Meskipun ketersediaan energi kurang, namun asupan energi santriwati $>50 \%$ dalam kategori sedang, hal ini disebabkan karena makanan yang diterima santriwati dipondok sudah menyumbang $>76 \%$ dan makanan dari luar pondok menyumbang $>5 \%$ dari $30 \% \mathrm{AKG}$

\section{Asupan Protein}

Tingkat asupan protein dari 63 orang 19 orang (30,16\%) memiliki tingkat asupan baik, 43 orang $(60,25 \%)$ memiliki tingkat asupan sedang dan 1 orang $(1,59 \%)$ memiliki tingkat asupan kurang. Tingkat asupan protein yang defisit ini sejalan dengan penelitian Rokhmah F, et al (2016) tentang Hubungan tingkat kecukupan energi dan zat gizi makro dengan status gizi siswi SMA di pondok pesantren Al-Izzah Kota Batu, bahwa tingkat asupan protein 30 orang $(67,00 \%)$ inadekuat.

Konsumsi protein yang defisit perlu ditingkatkan. Santriwati masih dalam masa pertumbuhan yang membutuhkan asupan protein yang cukup untuk tumbuh kembang yang optimal, selain itu juga dalam masa pubertas yang setiap bulan mengalami menstruasi dan membutuhkan prtoein dalam pembentukan sel darah merah $(\mathrm{Hb})$ guna mencegar terjadinya anemia (Arisman MB, 2009).

\section{Asupan Lemak}

Tingkat asupan lemak untuk dari 63 orang 22 orang $(34,92 \%)$ memiliki tingkat asupan baik, 12 orang $(19,05 \%)$ sedang, 17 orang $(26,98 \%)$ kurang, dan 12 orang (19,05\%) memiliki tingkat asupan defisit. Tingkat asupan lemak yang baik ini sejalan dengan penelitian Anggita (2016) tentang hubungan asupan energi dan lemak dengan status gizi pada remaja putri pondok pesantren Ta'mirul Islam Surakarta, bahwa tingkat asupan lemak 36 orang $(66,7 \%)$ dalam kategori baik. Konsumsi lemak yang cukup dapat membantu kerja metabolisme tubuh (Pakar Gizi Indonesia, 2016).

\section{Asupan Karbohidrat}

Tingkat asupan karbohidrat dari 63 orang 28 orang (44,44\%) memiliki tingkat asupan baik, 35 orang $(55,56 \%)$ memiliki tingkat asupan sedang. Tingkat asupan karbohidrat yang sedang ini sejalan dengan penelitian Hannik Rosida dan Annis Catur Adi (2017) tentang hubungan tingkat kecukupan energi, karbohidrat, protein dan lemak dengan status gizi pada siswa pondok pesantren Al-Fattah Buduran, Sidoarjo (2017) bahwa tingkat kecukupan karbohidrat 32 orang $(84,2 \%)$ dalam kategori cukup.

Karbohidrat merupakan seumber energi utama. Terpenuhinya kecukupan karbohidrat tentu akan menghemat cadangan energi lainnya untuk di pecah menjadi energi (Pakar Gizi Indonesia, 2016). Sehingga fungsi zat gizi lain yang terdapat didalam tubuh dapat berfungsi optimal.

\section{Asupan Zatt Besi (Fe)}

Tingkat asupan fe $100 \%$ defisit. Ketersediaan fe di pondok pesantren kurang, hal ini sejalan dengan tingkat asupan santriwati. Meskipun mendapat makanan dair luar konsumsi santriwati belum mencukupi kecukupan fe. Sehingga tingkat asupan santriwati masih defisit. Tingkat asupan yang defisit ini sejalan dengan penelitian Asriani, et al (2017) tentang Hubungan asupan zat gizi dan status gizi dengan hasil belajar IPA siswa pesantren MTs di Kabupaten Buru bahwa tingkat asupan zat besi (Fe) 42 orang (76,36\%) dalam kategori defisit. Penelitian ini juga sejalan dengan penelitian Qusna Nur Anisa, et al (2017), tentang Hubungan ketersediaan pangan dan asupan zat gizi dengan kadar hemoglobin santriwati saat puasa ramadan, bahwa tingkat kecukupan fe 29 orang $(67,4 \%)$ dalam kategori kurang. Kekurangan fe dalam jangka waktu lama akan mengakibatkan terjadinya anemia (Pakar Gizi Indonesia, 2016) 


\section{KESIMPULAN}

Terdapat 63 sampel dengan kelompok umur 13th-15th.Ketersediaan zat gizi bahan makanan selama 3 hari dalam kategori Kurang. Rata-rata ketersediaan zat gizi energi 75,2\%, protein $65,48 \%$, lemak 44,22\%, karbohidrat $97,65 \%$ dan 35,88\% fe. Asupan buka puasa didapatkan dari dalam dan luar pondok dengan tingkat asupan buka puasa energi 53,97\% Sedang, protein 46,03\% defisit, lemak 34,92\% baik, karbohidrat $55,56 \%$ baik dan fe $100 \%$ deficit.

\section{SARAN}

Untuk memenuhi kecukupan zat gizi santriwati perlu diperhitungkan kembali kecukupan zat gizi santriwati pada saat merencanakan menu. Diharapkan dari hasil perhitungan 30\% AKG, yang telah diterjemahkan kedalam menu buka puasa diharapkan menu yang telah direkomendasikan dapat di terima dan diaplikasikan, untuk memenuhi kecukupan zat gizi santriwati untuk buka puasa.Dari makanan yang dikonsumsi santriwati didapatkan bahwa konsumsi fe santriwati defisit. Sehingga perlu dilakukan penelitian lanjutan mengenai status anemia pada santriwati.

\section{DAFTAR PUSTAKA}

Anggraeni, Adisty C. (2012) Asuhan Gizi Nutritional Care Process. Yogyakarta:Graha Ilmu

Anggita D, Arifiyanti. (2016). Hubungan asupan energi dan lemak dengan staus gizi pada remaja pondok pesantren Ta’Mirul Islam Surakarrta.Skripsi Fakultas Ilmu Kesehatan. Universitas Muhamadiyah Surakarta.

Almatsier S.2009.Prinsip Dasar Ilmu Gizi. Jakarta: PT Gramedia Pustaka Utama

Anisa, Qusna, Nur Laksmi W dan Martha. (2017). Hubungan ketersediaan pangan dan asupan zat gizi dengan kadar hemoglobin santriwati saat puasa ramadhan. Kurnal Kesehatan Masyarakat.

Asriani, et al (2017).Hubungan Asupan zat gizi dengan hasil belajar IPA Siswa pesantren MTs Di Kabupaten Buru

Direktorat Pelayanan Medik Dasar. 2007. Pedoman penyelenggaraan Makanan Rumah Sakit (PGRS).

Hannik Rosida \& Annis Catur Adi.2017.Hubungan Kebiasaan sarapan, tingkat kecukupan energi, karbohidrat, protein dan lemak dengan status gizi pada siswa pondok pesantren Al-Fattah Buduran, Sidoarjo.Media Gizi Indonesia

Nur Hidayah, Nurul, et al (2016). Hubungan status gizi, asupan zat gizi dan aktifitas fisik dengan siklus menstruasi remaja putri pondok pesantren salafiyah Kauman kabupaten Pemalang tahun 2016.Jurnal Kesehatan Masyarakat (e-journal).

Kementrian kesehatan RI 2014 (pedoman gizi seimbang). (2014). kementrian kesehatan RI 2014 (pedoman gizi seimbang).

Kementrian kesehatan RI. 2013. Pedoman penyelenggaraan Makanan

Kementrian kesehatan RI. 2013. Riset Kesehatan Dasar.

Kementrian Kesehatan RI.2014.Pedoman Gizi Seimbang. URL: Tersedia dalam http://gizi.depkes.go.id/download/pedoman\%20Gizi/PGS\%20Ok.pdf Diunduh pada tanggal 8 Februari 2018.

Kementrian Kesehatan RI.2017. Tabel Komposisi Pangan Indonesia.

Kementrian Kesehatan RI.2017.Pemantauan status gizi (PSG) dan penjelsannya tahun 2016.

Kementrian Kesehatan RI.2019. Manfaat puasa

Kuspriyanto, Susilowati.2016.Gizi dalam Daur Kehidupan.Bandung:PT Refika aditama

MB, Arisman.2009.Gizi dalam Daur Kehidupan.Jakarta:EGC 
Ningtyias, F. W., Prasetyowati, I., Astuti, I. S. W., Muslicha, S., Nafi', A., \& Haryono, A. (2018). Gambaran Sistem Penyelenggaraan Makanan Di Pondok Pesantren, Kabupaten Jember. Medical Technology and Public Health Journal, 2(1), 25-34. https://doi.org/10.33086/mtphj.v2i1.314

Pakar Gizi Indonesia.2017.Ilmu Gizi Teori dan aplikasi. Jakarta:EGC

Putri, Isnaini K. 2016. Sumbangan makanan ringan terhadap kecukupan energi dan protein anak di TK ADE IRMA, Kraton, Yogyakarta. Skripsi Fakultas Teknik Universitas Yogyakarta

Rachmat Mochamad. 2017. Metodelogi Penelitian Gizi \& Kesehatan.Jakata: EGC

Rochmah F, et al. (2016). Hubungan tingkat kecukupan energi dan zat gizi makro dengan status gizi siswi SMA di pondok pesantren Al-Izzah Kota Batu.

Ronitawati, P, Setiawan, B dan Sinaga. 2016. Analisis konsumsi buah dan sayur pada model sistem penyelenggaraan makanan di sekolah dasar. Jurnal MKMi.

Rotua, M \& Siregar R. (2015). Manajemen Sistem Penyelenggaraan Makanan Institusi Dasar. Jakarta:EGC.

Rukmin L \& Suranadi L. 2015. Ketersediaan zat gizi siswi di yayasan pondok pesantren Nurul Hakim Kediri Kabupaten Lombok Barat. Jurnal Gizi Poltekkes Kemenkes Mataram.

Sinaga, T. \& Sudrajat, A. S., (2016). Analisis Biaya Makan Terhadap Ketersediaan Makanan Serta Tingkat Kecukupan Gizi Santri Di Pondok Pesantren Darul Arqam Garut. GIZI INDONESIA Journal of the Indonesian Nutrition Association, 2(2), 115-124. Retrieved from http://ejournal.persagi.org/go/

Sugiyono.2016.Metode Penelitian Kuantitatif, Kualitatif dan R\&D.Bandung: ALVABET CV

Supariasa, Bachyar Bakrie dan Ibnu Fajar.2014.Penilaian Status Gizi.EGC: Jakarta

Supariasa, Clara M. Kusharto.2014.Survei Konsumsi Gizi. Yogyakarta: Graha Ilmu 